\title{
NEGOTIATION OF TRADITION, ISLAM, AND MODERNITY IN THE KAUM MUDO ISLAMIC REFORM MOVEMENT IN MINANGKABAU
}

\author{
Andri Ashadi \\ Imam Bonjol State Islamic University Padang, Indonesia \\ E-mail: ashadiandri@yahoo.co.id
}

\begin{abstract}
At the beginning of the $20^{\text {th }}$ century, when the modernism of Islam was strengthened in Minangkabau, many academics viewed the Kaum Mudo movement paradoxically. On the one hand, it was considered to be progress-oriented by negotiating and accommodating adat, and as such, the followers were referred to as reformers. Conversely, the movement was seen as opposing and eliminating against the elemental integration of local cultures or adat and modern ideas into Islam. Hence, the supporters were also referred to as puritans. This article employed Stella Ting-Toomeys's identity negotiation theory, which refers to ethnic or traditional and religious identities as primary. Consequently, it was concluded that the Kaum Mudo Islamic reform movement in Minangkabau was rooted in religious customs and traditions and not purification. Furthermore, it was observed in several cases, such as the contests and fights for mutual influence by the existing social groups. It was also seen in the ethnic backgrounds of each character at times when attitudes, which give room for negotiations, are required. Meanwhile, the existing madrasa reform models negotiated between the traditional surau system and the modern Dutch school have displayed this movement. Finally, the existence of a synthesis of adat with Islam and modernity in Minangkabau, which are engaged in mutual negotiations, was also seen.
\end{abstract}

Keywords: The Kaum Mudo; negotiation; adat, Islam, modernity.

\section{Introduction}

The paradoxical relationship between adat and Islam in Minangkabau is an obsolete topic even though it has seized the 
attention of researchers. ${ }^{1}$ It is said that the Minang realm is one of the areas that experienced deep Islamization. At the same time, it is wellknown for defending matrilineal customs which are generally considered to be contrary to patrilineal-style Islam. The relationship between the two is described as a striking paradox in Islamic sociology. ${ }^{2}$ It's just that after the Paderi War the relationship was no longer seen paradoxically but was already in the form of a mutually symbiotic synthesis. In the Minangkabau local formula, it was agreed that "Adat Basandi Syara, Syara Basandi Kitabullah" (adat based on shara' and shara' based on the Kitäb Allah), hereinafter abbreviated as ABS-SBK.

Even so, the paradox perspective is still used by researchers in examining socio-religious issues in Ranah Minang. In appreciating the Islamic movement of the Kaum Mudo in the early 20th century, for example, many researchers placed them as reformers/modernists, but at the same time referred to as puritans/purifiers. As reformers, they are trying to change the ideas, customs, old institutions in the direction of the development of modernism. ${ }^{3}$ The Kaum Mudo are even considered to be towing the carriages of the Islamic reform movement not only in the Minahasa region but also for the context of Indonesia and the Malay World. ${ }^{4}$ They have become incubators who are heating up tensions between adat, Islam and modernity on the issue of ijtibād, education reform, and women's empowerment. ${ }^{5}$ The salient features of the movement are rooted in tradition and progressoriented (modernism), accommodative, evolutionary, and realistic. ${ }^{6}$

\footnotetext{
1 Alexander Stark, "The Matrilineal System of the Minangkabau and its Persistence Throughout History: A Structural Perspective", Southeast Asia: A Multidisciplinary Journal, Vol. 13 (2013), 1-13.

2 Taufik Abdullah, "Adat dan Islam: an Examination of Conflict in Minangkabau", Indonesia, No. 2 (October 1966), 1-24.

3 Harun Nasution, Pembaharuan dalam Islam Sejarah Pemikiran dan Gerakan (Jakarta: Bulan Bintang, 2002), 3.

4 Luthfi Assyaukanie, "Islamic Reform Movement in Indonesia and Beyond: Progress and Regress", Journal of Indonesian Islam, Vol. 2, No. 01 (2008), 131.

5 Jeffrey Hadler, Sengketa Tiada Putus Matriarkat, Reformasi Islam, dan Kolonialisme di Minangkabau, trans. Samsudin Berlian (Jakarta: Freedom Institute, 2010), 1; Deliar Noer, Gerakan Moderen Islam di Indonesia 1900-1942 (Jakarta: LP3ES, 1988), 37.

6 Muh. Saerozi, "Model of Strategies in Developing Islamic Thought through Curriculum: a Study of Sumatra Thawalib 1900-1942", IJIMS: Indonesian Journal of Islam and Muslim Societies, Vol. 4, No. 2 (2014), 233-255.
} 
Interestingly, at the same time, the puritan characters are addressed to them. Whereas in general, the purification movement opposes accommodation, let alone syncretism. Purification is an effort to eliminate local cultural elements from the basic elements of religion because they are considered as a source of heresy and khurāfat. The uncompromising attitude is also directed towards Western ideas and practices (modernism) because they are seen as damaging Islamic awareness and spirit. In this way, purification reflects a single religious tradition. ${ }^{7}$ In line with this framework, some accuse them of being the second wave of puritanism, continuing the tradition of purification of Islam in the Paderi's style. It's just that the strategy chosen is more moderate, focusing on the world of education, publishing books, magazines, and newspapers. ${ }^{8}$ Even though some of them have tried to integrate adat and shara' (Islam), they are still considered to have an obsession with eroding things that are heretical and khuräfat (puritanism). ${ }^{9}$ Based on the spirit of puritanism, according to other researchers, the Kaum Mudo reject the tarekat teachings and institutions, even though they have a place in the spiritual life of the Minangkabau people. ${ }^{10}$

The Kaum Mudo are also claimed to be resistant to the Minangkabau adat which gave birth to and raised them. The Kaum Mudo are not only considered to be attacking the religious practices of traditional ulama, but also adat, which is too exaggerated by adat. ${ }^{11}$ Resistance to adat was shown by Haji Abdul Karim Amrullah when

\footnotetext{
7 Joseph Tammey, "Modernization and Religious Purification: Islam in Indonesia", Review of Religious Research, Vol. 22, No. 2 (1980), 207-218; Ahmad Bunyan Wahib, "Being Pious Among Indonesian Salafis", Al-Jami'ab: Journal of Islamic Studies, Vol. 55, No. 1 (2017), 1-26.

8 Adri Wanto, "The Paradox Between Political Islam and Islamic Political Parties: The Case of West Sumatera Province", Al-Jami'ah: Journal of Islamic Studies, Vol. 50, No. 2 (2012), 348.

9 Novita Siswayanti, "Muhammad Djamil Djambek: Ulama Pembaharu Minangkabau”, Jurnal Lektur Keagamaan, Vol. 12, No. 2 (2014), 479-498.

${ }_{10}$ Nasrullah, "Respons dan Tantangan Kaum Tua atas Kritik Kaum Muda terhadap Tarekat di Minangkabau", 'Anil Islam, Vol. 9, No. 2 (2016), 214-246; Zulmuqim, "Transformation of the Minangkabau Islamic Education: The Study of Educational thought of Abdul Karim Amrullah, Abdullah Ahmad and Rahmah El-Yunusiyah," al-Ta'lim Journal, Vol. 22, No. 2 (2015), 155-164.

11 Azyumardi Azra, Surau Pendidikan Islam Tradisional dalam Transisi dan Modernisasi (Jakarta: PPIM UIN Syarif Hidayatullah Jakarta, 2017), xxxi; Azyumardi Azra, “The Transmission of al-Manar's Reformism the Malay-Indonesian World: The Cases of al-Imam and al-Munir," Studia Islamika, Vol. 6, No. 3 (1999), 4-28.
} 
he banned the procession of his father's death ceremony, despite the disappointment of members of his people. ${ }^{12}$ While the dualism of the tarawih prayer which ended with the celebration of Eid differs between the Kaum Mudo and the Kaum Tuo at a mosque in Padang City is another example of the Kaum Mudo resistance against the adat elite affiliated with the Kaum Tuo. ${ }^{13}$

An interesting question to ask is, "Is it true that the Islamic Movement of the Kaum Mudo is more puritanical; anti-tradition (Islam) and anti-Minangkabau tradition? "Using Stella Ting Toomey's identity negotiation theory, this paper will show the opposite that the reform of the Kaum Mudo Muslims is not anti-Islamic and antitraditional traditions. Even their Islamic renewal is rooted in adat which not only negotiates with Islam but also with modernity. This is based on the assumption that adat (ethnicity) and Islam (shari $\left.{ }^{-} a b\right)$ are the primary identity ${ }^{14}$ of the Minang people and certainly become a primary identity for the Kaum Mudo people. After the Paderi War, both of them could be negotiated into ABS-SBK which became the philosophy and worldview of the Minang people. The following narratives will prove this argument.

\section{The Kaum Mudo in the Negotiated Area}

Negotiations in a business institution may be an effort to accommodate various interests, so they are equally lucky. ${ }^{15}$ But the same thing is difficult to do especially in the context of fundamental differences such as norms, goals, and worldviews. ${ }^{16}$ These differences are to some extent difficult to be reconciled. Therefore negotiation is more a process of interaction that is bargaining both between individuals and between groups that strive in certain parts to state, explain, challenge and in other parts modify or support the self-image that is obsessed with them or to other groups. ${ }^{17}$ Stating, explaining

\footnotetext{
12 Noer, Gerakan Moderen, 37.

13 Zaim Rais, Against Islamic Modernism: The Minangkabau Traditionalists Responses to the Modernist Movement (Jakarta: Logos, 2001), 33.

14 Stella Ting-Toomey, Communicating Across Cultures (New York London: The Guilford Press, 1999), 28-36.

15 Charles P. Lickson J.D., and Robert B. Maddux, Negotiation Basics Win-Win Strategies for Everyone, Fourth Edition (Canada: Transcontinental Printing, 2005), 24.

16 Daisuke Minami, "Normalizing" Japan?: Contestation, Identity, Construction, and the Evolution of Security Policy", Honor Project, Paper 39 (2013), 16-20; Rawi Abdalal et.al, "Identity as a Variable", Perspectives on Politics, Vol. 4, No. 4 (2006), 697. 17 Ting-Toomey, Communicating Across, 40.
} 
one's own identity and challenging the identity of other groups is related to the efforts of individuals or groups in maintaining what is their identity/characteristic. While the attitude of changing one's own identity or supporting the identity of other groups outside the group can be understood as one way to avoid conflict. ${ }^{18}$ The framework of thought is useful for placing the Kaum Mudo in the negotiating room in at least two ways.

First, their position among other social groups. The challenges faced by the Minangkabau people at the beginning of the $20^{\text {th }}$ century were far more complex than the first $19^{\text {th }}$ century beheaded. At the beginning of the $19^{\text {th }}$ century, there were violent conflicts and frictions between adat represented by adat and puritanical Islam represented by "White People" or "Paderi People". Conflict and differences between the two led to social chaos and civil war (18031820) ${ }^{19}$ and continued with the war against the Netherlands which ended with the victory of the Netherlands in 1837 . Practically postPaderi War there are no more social groups that influence society and throughout Minangkabau submission under the Dutch colony. While in the early $20^{\text {th }}$ century the Minangkabau people experienced a multidimensional intellectual upheaval, even though physical conflicts and wars such as the $19^{\text {th }}$ century did not occur. From an internal perspective, there are debates related to orthodoxy and religious rationality such as the validity of the tarekat, khuraffat, heresy, qunüt, talqin, and ruqyah. There is also a debate about the validity of matrilineal inheritance law and the merit of the uneducated prince as a leader to the ideology of communism. ${ }^{20}$ While from an external perspective, just like other Islamic worlds, they were confronted with the current of modernism along with the presence of the (Dutch) invaders. It was in such a situation that social groups calling themselves the Kaum Mudo and their rivals, the Kaum Tuo, appeared in the dynamics of thought.

18 Georgiana Udrea and Diana Luiza Dumitriu, "Identity and Intercultural Adaptation Students' Adjustment Process to European Environments," International Conference RCIC'15 Redefining Community in Intercultural Context, Brasov, 21-23 May 2015.

${ }_{19}$ M.D. Mansoer, dkk., Sedjarah Minangkabau (Djakarta: Bhratara, 1970), 118.

20 Taufik Abdullah, "Sebuah Diktum Keramat dalam Sejarah Intelektual Minangkabau", Makalah pada seminar "Reaktualisasi Adat Basandi Syara' Syara' Basandi Kitabullah dalam Pembangunan Sumatera Barat", Bukittinggi, 22-23 Januari 2000. 
From the age factor, the term of the Kaum Mudo is aimed at younger groups or groups. On the other hand, The Kaum Tuo are targeting older groups. ${ }^{21}$ Like other young people, the Kaum Mudo Minangkabau supported the idea of modernization or at that time was popularly known as "progress" with a broad view and a critical attitude. ${ }^{22}$ Among the main figures are Muhammad Djamil Jambek (born 1860), Haji Abdul Karim Amrullah who is popular with the greetings of Haji Rasul (born 1879) and Haji Abdullah Ahmad (born 1895). All three are called the trio of Islamic reformers in Minangkabau because they live and carry out reforms at home. At the junior level figures such as Abdul Hamid Hakim, Buya Hamka, Labai El-Yunusiah and his younger brother Rahmah El-Yunusiah are also in this line. ${ }^{23}$ It's just that the so-called Young People in the Minang Realm do not always refer to specific groups. On the one hand, it refers to a religious group entity, the Kaum Mudo, as already mentioned. They criticized some traditional religious practices such as living closely and wanted social reform to create an advanced Islamic society. Even so, they claim that the ideas for reform are being rolled out and the socio-political activities carried out are still rooted in Islamic values. ${ }^{24}$ While the Ancient or Old People are anti-renewal groups and guard the continuity of tradition (tarekat) and adat. They were involved in a polemic with the Kaum Mudo on issues such as the validity of the tarekat, about khuräfat, bid'ah, qunüt, talqin, ruqvah problems and labelling them as Wahhabists. Khatib Ali, Muhammad Jamil Jaho, and Sulaiman al-Rasuli are ulemas who are in this group. ${ }^{25}$

Not only is the polemic between the Kaum Tuo, but also the Kaum Mudo people are involved in a polemic with the other Kaum Mudo, the Secular Kaum Mudo. The latter group refers to Westerneducated youths, from the families of prominent principals and Dutch government officials. Those who mostly live in the Dutch community

\footnotetext{
${ }^{21}$ Marah Rusmali, dkk., Kamus Minangkabau-Indonesia (Jakarta: Pusat Pembinaan dan Pengembangan Bahasa Departemen Pendidikan dan Kebudayaan Jakarta, 1985), 193, 305.

22 M.D. Mansoer, dkk., Sedjarah Minangkabau, 179.

${ }^{23}$ For further reading see Murni Djamal, DR.H. Abdul Karim Amarullah Pengarubnya dalam Gerakan Pembaharuan Islam di Minangkabau pada Awal Abad ke-20 (Jakarta: INIS-Leiden, 2002), 6.

24 Taufik Abdullah, Schools and Politics: The Kaum Muda Movement in West Sumatra 1928-1933 (Jakarta-Kuala Lumpur: Euinox Publishing, 2009), 8.

25 M.D. Mansoer, Sedjarah Minangkabau, 180; Rais, Against Islamic Modernism, 33.
} 
and receive the education of "King's School" also introduce the Dutch lifestyle, both in exclusive social clubs and through newspapers and magazines. ${ }^{26}$ As descendants of the aristocratic heads of families, they served to defend adat. Datuk Sutan Maharadja, which is often praised or ridiculed as a datuak bangkik (datuk bangkit) because he often campaigned to membangkik batang tarandam (traditional values) is one of the main figures of the secular Kaum Mudo. ${ }^{27}$

No less problematic is the external challenges presented by the Dutch colonial government in the field of education. Ethical politics required the Dutch colonial government to increase schools for indigenous people. If in 1913 there were 111 schools established up to the Nagari, ${ }^{28}$ by 1915 the number had risen to $350 .{ }^{29}$ The basic characteristics of the Dutch schools were neutral towards religion; not teaching religion, relying on rational thinking and liberal attitudes. It is feared that Minang children who are merely graduates of the school will be alienated from the identity of "Minang" and Islam and are less appreciative of religious leaders. ${ }^{30}$

Second, the background of ethnicity and character of the Kaum Mudo also shows a negotiative characteristic. Two of the main figures, Sheikh Muhammad Djamil Jambek and Haji Abdullah Ahmad were born from mixed Minang and non-Minang families. Sheikh Muhammad Djamil Jambek was born in Bukittinggi in 1860 from the father of a datuk father, Muhammad Saleh Datuk Maleka, an employee of the Dutch colonial government (head of the Kurai village, Bukittinggi) and a mother from Pasuruan, East Java. ${ }^{31}$ While his brother in arms, Haji Abdullah Ahmad was born in Padang Panjang in 1878 from a father named Haji Ahmad, a religious figure and businessman. While his mother came from Bengkulu. ${ }^{32}$ Psychologically both must be clever to place themselves, so they still have a place in the Minangkabau matrilineal kinship system. They are

${ }^{26}$ Gusti Asnan, Kamus Sejarah Minangkabau (Padang: PPIM, 2003), 126; Azra, Surau Pendidikan, xxx-xxxi.

27 Abdullah, Sebuah Diktum, 2.

${ }^{28}$ Nagari is the lowest unit of government system in West Sumatra that is equivalent to villages in Java.

${ }^{29}$ Azra, Surau Pendidikan, xxx.

30 Burhanuddin Daya, Gerakan Pembaruan Pemikiran Islam Kasus Sumatera Thawalib (Yogyakarta, Tiara Wacana, 1990), 111-112.

31 Noer, Gerakan Moderen, 42, Mestika Zed, ed., Pemikiran Minangkabau Catatan Budaya A. A. Navis (Bandung: Angkasa, 2017), 56.

32 Noer, Gerakan Moderen, 46. 
only anak bako (the name for the children of brothers), in the induak bako house (his father's sister) who are not entitled to inherit tribes, traditional titles and heirlooms from his father's family kinship. It would be easy to understand if then they did not join in opposing the customs or traditions (including the tarekat) maintained by the Kaum Tuo. ${ }^{33}$ The choices available to him are being nice with all groups, not to build groups and not join any organization. Muhamad Djamil Jambek, for example, agreed when invited by his friend Haji Abdul Karim Amarullah to establish Muhammadiyah in Minangkabau. But he himself is outside the organization. ${ }^{34}$

After living for nine years in Mecca while studying religious sciences, Djamil Jambek continued to teach in the surau in traditional ways. Even though he did not like the tarekat, his students which consisted of several teachers and leaders of the tarekat respected and regarded him as a member of the tarekat. ${ }^{35}$ Because of his accommodating attitude too, in the Japanese era, he was appointed chairman of the Majelis Islam Tinggi (MIT), a kind of Masyumi (Indonesian Syuro Muslim Council). In addition to preaching from the mosque to the mosque, he also established a famous mosque called Inyiak Djambek. Anyone can use it for religious purposes and religious organizations. His children tasted Dutch education and as a cleric-merchant, he owned a car, which was unusual in his time. ${ }^{36}$

Haji Abdullah Ahmad is more tactical in his dawah. Like the trader's tradition, he can work together with anyone for his ideals. He received help from the Dutch colonial government even from Chinese traders to build mosques or lottery funds (gambling proceeds) to build his school. After settling in Padang in 1906, he proved it. In addition to establishing the "Adabiyah Diniyah School", he also established a business unit to publish religious magazines and books which were funded by traders. From this business union, he expanded to other fields such as cooperatives, carpentry, to the cinema and insurance to finance the schools he founded. ${ }^{37}$ Because of this open and accommodating attitude, he was able to incorporate the Islamic religious curriculum into public schools (MULO), but because he received a subsidy from the Dutch colonial government, his school

${ }^{33}$ Hamka, Ayabku (Djakarta: Jayamurni, 1967), 202.

34 Zed, ed., Pemikiran Minangkabau, 56.

35 Noer, Gerakan Moderen, 43.

${ }^{36}$ Mestika Zed, Pemikiran Minangkabau.

37 Ibid., 57. 
then changed course. He received a school principal from a Dutchman and the management of his foundation was dominated by adat leaders from Dutch school graduates. ${ }^{38}$ Realizing this, he returned to his kbittah as an ulema. Together with Haji Rasul, he founded the association of Islamic religious teachers (PGAI) throughout West Sumatra in 1920. The "PGAI" then collectively sought the establishment of a religious teacher school, "normal school", as a statement that the school had a modern vision and was equivalent to a school country teacher. As a scholar loyal to the government, along with Djamil Jambek, he had received an award from the Dutch kingdom. ${ }^{39}$

Different from the two previous figures, Haji Rasul (born 1879 in Maninjau) has both parents who are from Minangkabau. His father, Muhammad Amrullah Tuanku Kisai, was an ulama, murshid of the Shattarìyah tarekat, the grandson of Tuanku Pariaman. While his mother, Siti Tarsawa, was born in Maninjau. As a product of matrilineal culture, ${ }^{40}$ he has the moral courage to criticize his own traditions and customs. He not only criticized the Indigenous Peoples and the Kaum Tuo, but he also criticized the invaders so that the three groups opposed them. But the criticism that threatened his life was directed at the colonial government. During the Dutch colonial administration, he was arrested and exiled to Sukabumi without trial for extreme opposition to "teacher oration and wild school oration". 41 If not mediated by Muhammad Hatta, the Japanese military almost beheaded him for disagreeing with seikerei; bowing towards the rising sun as a symbol of the reign of the Japanese emperor. ${ }^{42}$

But the hard attitude is not always consistent. Haji Rasul, for example, criticized the cino buto ${ }^{43}$ marriage pattern, which he

\footnotetext{
${ }^{38}$ Ibid.

${ }^{39}$ Ibid., 58

40 Matrilineal culture is a principle that promotes equality. In the case of leadership, for example, it is guided by the customary values of deliberation and munfakat while the appreciation and appreciation of leaders is only appropriate.

${ }^{41}$ Ismatu Ropi, Religion and Regulation in Indonesia (Singapore: Palgrave Macmillan, 2017), 51.

42 Zed, ed., Pemikiran Minangkabau, 55.

43 Referring to the Minang community tradition at that time, where a husband and wife divorced until divorce three but then wanted to reconcile, then the wife must first marry another man before referring to his first ex-husband, a wife must marry another man as an "intermediary". As an intermediary, the other man is positioned
} 
considered violated Islamic law, but he was unable to break away from the practice of marriage and divorce many times as was the custom of the adat and ulama of his time. He is even referred to as "the serial divorcee who is uncompromising". "Hamka noted that there were 12 of his father's wives and the most common practice of divorce marriage (with three wives) occurred when he taught in Padang Panjang. ${ }^{45}$ To the extent that the grandmother on the part of Hamka's mother accused Haji Rasul of neglecting the family, "Hajj teacher! Pilgrimage teacher! Why are children abandoned?"46 That is, behind the hard and critical attitude there is still room for negotiation and accommodation, though not as broad as the two previous figures. The third character's negotiating and accommodating character will be increasingly seen in the following two models of Islamic renewal.

\section{Madrasas Existence between Two Systems}

Educational institutions are the main setting for the modernization/renewal process. This appears in various parts of the world such as in Spain, Italy, Sweden and blows into the Islamic world such as Egypt, including to the Southeast Asian region. ${ }^{47}$ The emergence of the Kaum Mudo madrassas, especially the Thawalib and Diniyah Puteri Colleges in Padang Panjang, can, on the one hand, be regarded as a response to the Dutch modern education system and the traditional education system of the Kaum Tuo people. While in other parts it is more than just a response, but it is a negotiation between two opposing educational systems.

At that time, the Kaum Mudo worried that Dutch schools which were secular, rational, and liberal would have implications for the authority and respect for Islamic scholars and intellectual intellectualism, especially among the younger generation. This policy was designed by the Dutch indeed with a dual purpose, in addition to preventing the development of a radical Islamic movement that was suspected of appearing through a surau institution, as well as to train

only to justify certain provisions, time, and payment so that he can refer to his exwife who has been denied all three. See Hadler, Sengketa Tiada Putus, 141.

44 Ibid., 232.

${ }^{45}$ Hamka, Ayabku, 262-263.

${ }^{46}$ Hadler, Sengketa Tiada, 235.

47 Tammey, Modernization, 207-218, Assyaukanie, Islamic Reform, 131. 
low-ranking bureaucratic personnel to be placed in each region. ${ }^{48}$ But in the context of Minang children's education, it has other implications. On the one hand, it can guarantee the progress and graduation of students on time, but on the other hand, it actually uproots them from their cultural roots. The story of Abdul Riva'i who merely tasted Western education is often used as an example. The Minang people are proud of themselves especially when they help raise the issue of discrimination and injustice experienced by the indigenous population (including the Minangkabau people). But he seemed alienated from his own society when he married a Christian woman and a Dutchwoman. ${ }^{49}$ In addition, the community's need for more schools was apparently not met by the Dutch government or by traditional groups (Kaum Tuo). This increase is in line with changes in the mindset of indigenous people towards education. If previously going to school was considered to be able to cause a person to become an "infidel," then in 1919 there were even many complaints about the lack of educational facilities. Of the 200 Stovia pupils, said LeFebvre (1919) West Sumatra Resident who was socialist and sympathetic to the Kaum Mudo movement, 70 people came from West Sumatra. ${ }^{50}$

The above context is the basis of why on one side the Madrasas of the Kaum Mudo still accommodate certain features of the suran education system. But at the same time, the existence of madrassas was also open to other characteristics of Dutch education. That is, these schools are both traditional and modern. In terms of the eclectic curriculum, the content of religious subjects such as figh, tafsir, hadith, 'ulum al-Qur'an as one of the treasures of the traditional education system of surau is still maintained which is integrated with worldly sciences such as Dutch, English, mathematics, earth science and so. It's just that they left the haläqah system, an irregular curriculum, untrained teachers, unclear graduation or graduation systems and the habit of making students into faqir or urang siak. ${ }^{51}$

\footnotetext{
48 Daya, Gerakan Pembaruan, 261.

${ }^{49}$ Noer, Gerakan Moderen, 51.

50 Abdullah, Sebuah Diktum, 3.

51 Sometimes they are called urang siak (claimants of religious knowledge) and not infrequently also referred to as faqir people. Both of these terms refer to the ways in which students meet their daily needs while studying in surau or madrasa because in general they are not provided with adequate logistics from their hometown. As urang siak they provide practical religious services, especially leading a prayer to the people
} 
Instead, they introduced modern teaching methods, class systems, the use of tables and chairs, a systematic and orderly syllabus and payment for the cost of organizing education in imitation of the Dutch education system. ${ }^{52}$ As Islamic reformers, they are aware of the weaknesses of the surau education system such as the halaqah system. Mahmud Yunus, one of the teachers at this madrasa with a little exaggerated mention that the halaqqah system is only able to give birth to one cleric out of a hundred people who are interested, the rest is just simply "enlivening" the learning process at the halaqqah. ${ }^{53}$

The same negotiating and accommodating attitude is also shown towards something that comes from a foreign culture which seems to be the reason why they take certain sides of the Dutch education system and reject the other side. In an agitative appeal, Haji Rasul did not hesitate to invite Muslims to learn all the knowledge that is necessary and beneficial for the life of the world and the hereafter of Europeans, Americans, Africans, Hindustans, Turks, Australians, and Japanese. But he warned that in matters of religion only governed by Islamic values, not by Western ways of thinking and teachings. ${ }^{54}$ This paradigm of thinking is clearly a major revolution, especially in the midst of Kaum Tuo orthodoxy and Dutch hegemony. It is also difficult to understand if it is related to the character of Haji Abdul Karim Amarullah who is described by his son, Hamka, as "Stubborn, straightforward, puritanical, arrogant, strong, fanatical, and high tempered". ${ }^{55}$ However, Haji Rasul's inclusive-negotiative attitude seemed to find a foothold when it was associated with the ideology of ijtihäd which became the mainstream of the Kaum Mudo movement. Haji Rasul encourages ijtibäd to always be carried out; use reason to understand and study the universe and

in the villages around surau or madrasa. The community then offers assistance in the form of food or other needs. This activity is commonly referred to as mamakiah from the word pakiah (faqih); people who understand the Islamic sciences, especially fiqh. The mamakiah tradition is still preserved by the Salafiah pesantren in several areas in West Sumatra. Andri Ashadi, dkk., Tradisional di Tengah Perubahan Studi Kasus Pesantren Salafiah Kabupaten Padang Pariaman (Padang: Puslit IAIN Imam Bonjol Padang, 2011), 53.

52 Djamal, DR.H. Abdul Karim Amarullah, 64.

${ }^{53}$ Mahmud Yunus, Sejarah Pendidikan Islam di Indonesia (Jakarta: T. Hidakarya Agung, 1996), 58.

${ }^{54}$ Ibid., 48.

${ }^{55}$ Hamka, Ayabku, 117. 
use it for happiness. Instead, he criticizes the muqallid (the Kaum Tuo) as people who ignore the dynamic needs of contemporary religious life because they are unable to use reason to understand various changes in the order of life including religious life. ${ }^{56}$

To maintain and inherit the above system, Haji Rasul introduced a seminar system for the highest class of students. Students consisting of intelligent and experienced students are given the opportunity to expose problems with arguments that make sense if criticized by others. For this reason, students are encouraged to master mantiq as a tool to maintain the ideas and science of usül al-fiqh in order to refer to authentic sources. By practising a system of discussion and seminars, he believes that students will be able to maintain freedom of thought without basing opinions on any educated person in the manner of taqlid (blind acceptance). ${ }^{57} \mathrm{He}$ himself used some of his time in the morning to give special lessons to students and teachers to be proficient in analyzing, debating using science mantiq. Every Wednesday night a meeting is held to discuss anything religious, including the customary relationship between the Minangkabau and Islam. All issues are discussed freely and debates take place between students and teachers. On the one hand, this has changed the passive culture formed by the halaqah system so that students including teachers become active. On the other part, it encourages them to also appear as creative leaders in the midst of society. So it is not surprising that aside from being teachers or preachers, organizations such as "Islamic Syarikat"/Syarikat Islam (SI), "Indonesian Muslim Association"/Persatuan Muslimin Indonesia (1930) and "Indonesian Islamic Party"/Partai Islam Indonesia (1938) used them as propagandists. It is not uncommon for him to join the communist movement, although it is not necessarily related to his understanding, but rather on radical attitudes and steps that are believed to bring the liberation of the country closer to colonialism. Therefore, Thawalib then became the nursery of various nationalist movements; Islam, nationalist, and communist. ${ }^{58}$

T. Van der Plas, head of the office of Indigenous Affairs of the Dutch Government, praised that teaching in schools was of very high quality and was not based on learning by memorization, but more on

\footnotetext{
${ }^{56}$ Djamal, DR.H. Abdul Karim Amarullah, 38.

${ }^{57}$ Ibid., 68-69.

58 Deliar Noer, "Introduction" in Burhanuddin Daya, Gerakan Pembaharuan, xx.
} 
thinking and understanding. The same positive assessment and appreciation also came from B. Schrieke, a well-known Dutch scientist and researcher of the communist uprising in Minangkabau, who stated: "The Sumatra Thawalib School has a very good reputation because competent religious teachers teach there (the late Zainuddin Labai and Haji Rasul) and the teaching system, as is customary today more or less adapted to modern requirements". ${ }^{99}$ It takes 12 years of study according to the al-Azhar education system to achieve what was accomplished in seven years in Sumatra Thawalib. ${ }^{60}$ Sumatra Thawalib with a 7-year teaching system is able to teach 12 kinds of religious subjects including Arabic by using books from the lowest level that are usually written by the teachers themselves to the highest level books imported from Egypt or the Middle East. Meanwhile, if you follow the traditional system of surau that has been abandoned to study fiqh alone, a student can spend between 10-15 years. $^{61}$

Of course, the Madrasas of the Kaum Mudo are not a model of thought. Haji Abdul Karim Amarullah is the most aggressive figure among modernist, fanatical, and most feared clerics by his opponents; Muhammad Jamil Jambek is a practical human being, he is the most persuasive and most influential among modernist scholars; then Haji Abdullah Ahmad is more a writer than a teacher, more a universalist Muslim than a Malay Muslim. ${ }^{62}$ At least it was seen when he founded Adabiah School in 1907 in Padang Panjang. He is actually an early figure in the transformation of traditional surau into a modern madrasa that integrates both religious and general subjects. But in its development, this school changed direction when receiving subsidies from the Dutch colonial government. Adabiyah instead prioritizes general subjects and adapts to the government school system, the Hollandsch Inlandsche School (HIS). Instead of being a milestone in reform activities, it failed because of Western orientation and pressure, so that the school led by Haji Abdullah Ahmad was outside the mainstream of the Kaum Mudo community. ${ }^{63}$ His student, Kiai Haji Zarkasyi, founder of Pondok Gontor Ponorogo who had studied

\footnotetext{
59 Ibid.

${ }^{60}$ Yunus, Sejarah Pendidikan, 76.

${ }^{61}$ Kementerian Penerangan Indonesia, Propinsi Sumatera, 865.

${ }^{62}$ Djamal, DR.H. Abdul Karim Amarullah, 22.

${ }^{63}$ Noer, Gerakan Moderen, 52.
} 
at this school stated that "Abdullah Ahmad is not a modernist, but a Hollandisator", 64

But as explained at the beginning of this sub-theme, are the above negotiative-accommodative attitudes of the Kaum Mudo people merely a response to the traditional education system of surau and the modern Dutch education system? If it is only a response, why is it in the condition of the deterioration of the Dutch education system and the modernity of Dutch education with superiors' subordinate strength, the response appears in the form of synthesis between the two. Is not theoretically agreed that one of the social and psychological obstacles that prevent social change is a very striking social inequality. ${ }^{65}$ At least in this context, the Kaum Mudo are involved in a violent polemic with the Kaum Tuo on various religious issues including the issue of education. While the Netherlands as the dominant political force organizes education for indigenous children within an ethical-political framework which has also become a particular concern among Mudo. Indeed all of this is outside the ABS-SBK framework. But using Taufik Abdullah's problematization theory, cannot the external elements always be accommodated by the concept of customary adat (a custom that prevails in the general public/local or in the artificial plural) (values created later by agreement can also be due to the compulsion of circumstances). Isn't this what is referred to in the phrase as kato kudian kato bacar? (then the word that is sought). Isn't it also that jihad using reason to achieve progress is also something advocated by Islam? In this context, it is more than just a response but on this site is a negotiation between adat, Islam and modernity that gave birth to synthesis in the form of progressive, Islamist, accommodative and inclusive madrassas belonging to the "Kaum Mudo".

\section{The Existence of Women in School}

As adherents of the largest matrilineal system in the world, ${ }^{66}$ women have an honoured position in Minangkabau adat. From birth

\footnotetext{
${ }^{64}$ Karel A. Steenbrink, Pesantren, Madrasah, Sekolah Pendidikan Islam dalam Kurun Moderen (Jakarta: LP3ES, 1986), 42.

${ }^{65}$ Robert H. Lauer, Perspektif tentang Perubahan Sosial (Jakarta: Bina Aksara, 1989), 12 14.

66 Suryadi, "Resistensi Nasab Ibu Terbesar di Dunia", http://cetak.kompas.com/ $\mathrm{read} / \mathrm{xml} / 2009 / 04 / 19$ / 0416563/resistensi.nasab.ibu.terbesar.di.dunia (14 Maret 2019).
} 
to marriage, they are called gadih children (girls), a period of preparation as potential heirs to the Minangkabau tradition. They experienced the internalization of the values of Minang tradition in the family environment of the batib family and his people. The term then turns into padusi when they are married. The term padusi literally comes from the word padu (fused) into padusi, referring to married girls. Her existence has begun to be taken into account, because she plays the role of a wife and is able to live a broader life in the gadang house, becoming a daughter-in-law in her husband's extended family. The phase of inhabiting a gadang house with all its ups and downs and how it uses adat to solve the problems of its life is referred to as parampuan (women). The climax, the women will get the highest and honourable predicate, namely bundo kanduang, when appointed as the head of the woman, determining the policy taken at the gadang house. $^{67}$ In Kaba Cindua Mato (classic Minang narration), Bundo kanduang is imaged as the king who controls the government in the kingdom of Pagaruyung, as well as being a good and wise mother. This is reinforced by the mamangan who refers to women as limpapeh rumah nan gadang which gives recognition and some privileges to women in society. ${ }^{68}$ In another phrase, it is said that although men cannot be separated from the lives of their wives and children, the centre of life, especially heritage and profession, is controlled by women or wives. ${ }^{69}$

It's just that the great narrative and domestic greatness in the gadang house are not directly proportional to its strategic role in public spaces. Until the $20^{\text {th }}$ century, the public role of Minangkabau women was not widely revealed. What emerges is precisely the variety of narratives that corner and subordinate them into a child who is secluded, waiting to be married, and is expected to soon have a husband. If the daughter has reached the age of 15 or 18 years old, writes Djoeriah in Soenting Melajoe, the priority for her mother and father is to prepare everything for her child's festivity. The next two

${ }^{67}$ Gusna Ronsi, “Citra Perempuan dalam Peribahasa Etnik”, Wacana Etnik: Jurnal Ilmu Sosial dan Humaniora, Vol. 2, No. 1 (2011), 39-58.

68 Mina Elfira, "Bundo Kanduang: a Powerful or Powerless Ruler? Literary Analiysis of Kaba Cindua Mato (Hikayat nan Muda Tuangku Pagaruyung)", Makara Sosial Humaniaro, Vol. 11, No. 1 (2007), 30-36.

69 Dedi Arsa, "Perempuan Memberontak: Perlawanan Perempuan Minangkabau terhadap Kolonialisme Belanda di Sumatera Barat 1908-1942", Kafa'ah Journal, Vol 7, No. 1 (2017), 45. 
or three months were then searched for who deserves to be his match. A girl can be married to a person who is twice her age, especially if the person concerned is a prince, tuangku laras, or a government employee. Not stopping there, she was prepared to be polygamy by her husband, marriage, and divorce many times with different couples. Because of the frequency of marriage, a husband no longer knows his own children. Hamka dramatically related:

"One day a man returned to his home outside of his usual habit, which is midday. Then the child met who was playing in the middle of the yard. The boy then rebuked, as is the custom of children who learn good manners, "Where are you going mamak (uncle)?" The father was stunned and almost angry. Then he asked his wife why his child said that. The wife is also angry with her child, why call uncle to his father. While the child had felt himself innocent and should not be scolded". ${ }^{70}$

While girls are secluded, boys no longer sleep in gadang houses or in their parents' homes when they are in their teens. They were sent to the mosque to learn to read the al-Qur'ān, matters of worship, qasidah (Arabic songs) and barzanji (the life history of the prophet that is always told at the time of his birthday), ${ }^{71}$ hone the skills to tell stories, and learn about wider life from travellers and widowers sleeping in the mosque. ${ }^{72}$ Therefore suran education is actually synonymous with education for boys.

From the perspective of the Kaum Mudo people at that time, this fact was later deconstructed by their understanding. Sumatra Thawalib, the Kaum Mudo School which was originally a suran (Jembatan Besi) accepts not only male students but also female students. One of his famous female students is Rahmah El-Yunusiah. He spent almost eight years of his life studying at this school under the direct guidance of the Haji Rasul. ${ }^{73}$ Interestingly, this took place when his orthodox views on the domestic role of women remained strong until the Muhammadiyah conference in Ranah Minang in 1929. The conference recommended that women be allowed to take part in religious activities as well as men. For example, attending conferences in Minangkabau or in other areas. ${ }^{74}$ The involvement of women to

\footnotetext{
${ }^{70}$ Hamka, Islam dan Adat Minangkabau (Jakarta: PT Pustaka Panjimas, 1984), 44.

71 Yunus, Sejarah Pendidikan, 8.

${ }^{72}$ Hadler, Sengketa Tiada Putus, 192-193.

${ }^{73}$ Djamal, Dr. H. Abdul Karim Amrullah, 60.

74 Ibid.
} 
follow the flow of educational progress initiated by the Kaum Mudo people became more apparent when Labai El-Yunusiyah established the Diniyah School, or Diniyah Putri, which was prepared primarily to accept female students. This school opened the eyes of women to school and showed rapid development when his younger brother Rahmah Elyunusiyah led the school. ${ }^{75}$

Diniyah school implies to bring up another style of the madrasa of the Kaum Mudo because it accepts students not only boys but also female students from various regions of the archipelago, including those who come from Malaysia. In the two decades of the $19^{\text {th }}$ century, there were at least 39 Mudo schools with an estimated number of students of around 17,000 and each year produced thousands of graduates. Those who are educated with various abilities and skills such as rhetoric and debate both in Sumatra Thawalib and in Madrasah Diniyah after graduating from various professions; became a missionary, journalist, merchant, activist movement, and often founded a madrasa with the same prototype. Among them was done by Haji Jalaluddin Thaib in Tapak Tuan Aceh, which was inaugurated by Haji Rasul himself. Likewise by followers in Bengkulu who called their madrasa Mubibb al-Ihsañ (virtue lover). ${ }^{76}$ Become a madrasa and alumni as a network for spreading ideas for the reform of the Kaum Mudo people who are rolling into various regions of the archipelago. This condition benefited from the ambiguous Dutch colonial government education policy; on the one hand promoting initiatives to establish private schools but as far as possible without additional financial obligations. ${ }^{77}$ As a result, religious schools, especially Sumatra Thawalib in Padang Panjang, are becoming increasingly famous because they produce graduates who are prepared to become community leaders.

Women do not just go to school, they are even involved in politics. Of the approximately 10,000 members of Permi (Indonesian Muslim Association), 40\% of them are women and of around 86 "Permi" branches and subsidiaries, 37 of them are Permi Women. His first conference, July 1932 in Bukittinggi specifically about women with almost all the speakers also women. They discussed the emancipation of women and the position of women Minang

75 Ibid.

${ }^{76}$ Hamka, Ayabku, 64.

77 Djamal, Dr. H. Abdul Karim Amrullah, 73. 
customs. $^{78}$ If so, if progress is also a concern of Islam and education is one of the ingredients, then isn't Minangkabau a matrilineal society? Then should women also go to school? At this level, it seems increasingly reasonable that the negotiative and accommodative attitudes of the Kaum Mudo in managing the education system are more than just a response to the traditional Dutch surau and modern system, but a negotiating effort that is still selectively rooted in adat, Islam, and modernity. Therefore their rhetoric and criticism of adat as mentioned earlier is actually not intended to damage or neglect adat, but instead, strengthen it especially in line with their renewal ideas. In addition, as Muslim reformers, the Kaum Mudo are not completely free from the social structures that underlie and raise them. Above all these social structures have provided social and intellectual advantages, where they have been placed at the highest social hierarchy. They are strongly connected to the idea of progress that was the aspiration and obsession of the Minang people at that time. ${ }^{79}$

\section{Custom, Islam and Modernity; A Negotiation-Synthesis}

The next question that needs to be answered is, "How can the established Minang adat negotiate with Islam and modernity that emerged lately?" Long before the presence of Islam and the Dutch colonialists with their modernity concept, the Minang people had settled into the adat system. Therefore custom is interpreted as an ideal pattern of behaviour that includes all living systems; individual and communal habits, etiquette and norms, including social and political structures. ${ }^{80}$

It's just that as an ideal pattern of behaviour, adat is formulated in a dialogic relationship with nature, remembering that transcenddental-divine elements only emerge later along with the presence of major religions, especially Islam. The natural elements which appear to be different are brought together in a system of contradiction and balance. How are these values met? Just, for example, Nasroen, the author of the Falsafab Adat Minangkabau explained it with curry metaphors. In cooking, curry used different ingredients including salt, chilli, and star fruit. Even though it has become curry, saltiness, spicy

\footnotetext{
78 Daya, Gerakan Pembaruan, 296.

79 Taufik Abdullah, "Islam, History, and Social Change in Minangkabau", in Taufik Abdullah, ed., Change and Continuity in Minangkabau: Local, Regional, and Historical Perspectives on West Sumatra (Jakarta: LIPI, 1985), 162-162.

80 Abdullah, Adat dan Islam, 1.
} 
chilli, and starfruit acid are insoluble and can still be distinguished even in taste. If something is lacking from one of the elements, then the curry will feel uncomfortable because of the lack of balance of the various elements in one unit. Thus curry is a unity where conflicts are in balance, interconnected but not eliminating. ${ }^{81}$

From the perspective of alam takambang jadi guru, it is certainly easy to understand if the contradictory-negotiative nature of the elements of nature is also reflected in the contradictory-negotiative nature of adat elements. This, for example, is seen in the customary polarization which is sorted into categories; adat nan sabana adat, adat nan diadatkan, adat nan teradat, dan adat istiadat. ${ }^{82}$ Although there is a category of adat nan sabana adat (Islamic adat, fiqh laws), it does not necessarily mean that other custom categorizations are excluded and are not recognized, because they are actually drawn in the ranks of adat nan sabana adat. This categorization according to Taufik Abdullah is a way to overcome the tension between what should be and what happened. ${ }^{83}$

The contradictory-negotiative nature of adat values also manifests in the social structure and political structure of the Minang community. The traditional social structure of Minang can be divided into two opposing systems. Patrilineal royal kinship system and matrilineal kinship system of ordinary people. However, both are an inseparable part of the Minangkabau realm. In one sense, royal descent can be considered a representation of male principles, whereas society mostly represents female principles. It's just that the two principles were combined through marriage which did not distinguish the social status between nobles and ordinary people. Likewise, the structure of politics. ${ }^{84}$

The Minang traditional area can also be divided into two. The first is called lubak or darek (land), which is a plateau area on the slopes of Mount Merapi and Singggalang. This was the initial settlement of the Minangkabau which included three lubak; Tanah Datar, Agam, and 50 Cities. Second, what is called the rantau, namely the area that is controlled at a later date or expansion of the Darek region. Although the royal kinship system is recognized and is a supra

${ }^{81}$ Nasroen, Dasar Falsafah Adat Minangkabau (Jakarta: Bulan Bintang, 1989), 149.

82 Safruddin Halimy Kamaluddin, Adat Minangkabau dalam Perspektif Hukum Islam (Padang: Hayfa Press, 2005), 32-35.

83 Abdullah, Adat dan Islam, 114.

${ }^{84}$ Ibid. 
system, it does not necessarily mean that the two categories of territory above are under the reign of kings. Only the overseas territories that encircle the Minangkabau region are governed by the king or vice-king, while the nagari in the third lubak are ruled by the prince. The sociological consequence is that only in overseas areas the distinction between aristocrats and non-aristocrats can be applied because it is based on territorial provisions. But this is not the case in the darek region which has a social structure based on genealogy. Although in both regions it is not uncommon for competition and institutional conflicts that sometimes erupt into open warfare, each region needs each other. Darek in historical writings is often referred to as rich in gold and spices such as coffee and secondary crops which became a commodity of world trade at that time. While overseas areas such as Tiku Pariaman are trade centres. ${ }^{85}$ But even more important is that both are alike bound to the ideal behaviour patterns that provide a place for each other. In adat tambo it is stated that, overseas as a window into the outside world functions as an interpreter of religious preaching for the interior, darek. Therefore called religion (Islam) rises from the plains, coast into the interior, darek. While darek as the origin of the Minang tribe is a source of adat, it is said that adat descended from the highlands of Darek to the overseas coastal areas. ${ }^{86}$

The presence of Islam as a newcomer does not really change the adat system and the double-negotiative social-political structure above. Islam, according to Taufik Abdullah, ironically added another dimension which became the basis for strengthening existing tensions. Islam faces a tension between universalism aspired to and particularism. This is stated in the normative standard of behaviour patterns in Islam based on two opposing poles; between the mandatory and the forbidden (baräm). Since most human actions are not in these two categories, the next category appears; sunnah, makrūh, and jäir/mubäh. ${ }^{87}$ In addition, in Islam it is also recognized to deal with problems that are not found in the Qur'ān and the Hadìth, then the next reference can turn to qiy às or ijmä of ulema, where reasoning

85 Rony Saputra, Ketika Kebebasan Beragama, Berkeyakinan, dan Berekspresi Diadili (Padang: LBH Padang, 2013), 43. See Irhash A. Samad and Danil M. Chaniago, Islam dan Praksis Kultural Masyarakat Minangkabau (Jakarta: Tintamas, 2007), 61-63.

${ }^{86}$ Abdullah, Adat dan Islam, 10.

87 Ibid. 
is the keyword. In this context, terma adat is often synonymous with the term 'urf in the Islamic tradition, which is something that is equally known by one community of people and is accepted as something good. ${ }^{88}$ So that later it is understood that there is no difference between adat which is actually adat and Islamic doctrine. The reason is because adat which is actually custom is based on natural laws while natural laws in the Islamic perspective are believed to be God's natural cues that must be studied and believed as well as the necessity of studying and believing in the verses of qawliyah, alQur'ann. This in fact strengthens the position of adat as 'urf beside Islam as transcendental divine values. Therefore, what happens based on the results of Djoko Suryo et. al's research is the negotiation process between adat and Islam. ${ }^{89}$

The above is seen in the initial negotiations between adat and Islam which were standardized by the phrase Adat Basandi Syara, Syara' Basandi Adat. This means that both religious values and values are equally valid. This is also reinforced by many studies that state that Islam that reaches Indonesia, especially in the Minang realm, is Sufitarekat-style Islam which deals more with "purity of heart" than truth or appropriateness in behavior. So that from this framework the hypothesis can be derived that under the influence of Sufism in a low level and local culture that has not been established, the process of spreading and accepting Islam tends to move towards the pattern of indigenization as is the case with Islam in Ternate. Conversely, under the influence of Sufism in high levels and established local culture, the pattern of integration tends to move towards Islamization as in the case of Aceh. Only under the influence of strong Sufism and established customs also in the Minang realm, the integrative pattern actually moves towards negotiations. This hypothesis indeed shifts some of the previous theses which mention that the Minang realm is one of the regions experiencing massive Islamization. ${ }^{90}$ Islam, for example, did fill other regions in the political structure of the postAditiawarman government in the 16th century with the emergence of

\footnotetext{
88 Amir Syarifuddin, “Adat Basandi Syara' Syara' Basandi Kitabullah”, dalam kumpulan makalah "Seminar Reaktualisasi Adat Basandi Syarak, Syarak Basandi Kitabullah dalam Pembangunan Sumatera Barat", Bukittinggi, 22-23 Januari 2000, 2.

${ }^{89}$ Djoko Suryo, dkk., Agama dan Perubahan Sosial Studi tentang Hubungan antara Islam, Masyarakat dan Struktur Sosial Politik Indonesia (Yogyakarta: LKPSM, 2001), 16.

90 Abdullah, Adat dan Islam, 104.
} 
rajo tigo selo (king of three thrones); natural king, custom king, and worship king. However, this appears more as a differentiation of authority according to their respective fields. The king of nature in Pagaruyung has authority in matters of government, the customary king in customary affairs and the king of worship governs matters of religion or worship. ${ }^{91}$ The same pattern is also seen in the inheritance of heirlooms which has consumed Minang intellectual attention. Assets are divided into two forms; high pusako and low pusako. High pusako is a communal treasure whose inheritance pattern is hereditary but because it is difficult to trace its original source, it is regulated by an adat system. While rukah pusako is the result of a husband and wife search not from a high pusako. This is what the pattern of inheritance uses faraid. Even when the integration phase which showed Islamic domination over adat even with ABS-SBK adage, some customary provisions such as tribal formation, exogamy marriage system, matrilocal and uncle and nephew inheritance pattern still prevailed in the social life of the Minang people who continued to prioritize the pattern of negotiation rather than the pattern of Islamization. ${ }^{92}$ This synthesis-negotiative pattern is then neatly illustrated by Hamka as "a mixture of water and oil in milk" rather than a combination of "water" and "milk". 93

Like the presence of Islam which did not Islamize the basic structure of adat and the socio-political structure of the Minang community, the presence of the Dutch as a political determinant did not affect the existing polarization, both on adat and on Islam. The Netherlands actually exploits and takes advantage of these conditions. Theoretically, the Netherlands is said to have carried out neutral politics towards religion and did not involve themselves in a variety of fundamental problems in the villages of Ranah Minang; customs, religion and withdraw tribute (tax) directly from the community. ${ }^{94}$ However, in practice, the colonial government was only tolerant of religious worship and acted decisively towards so-called fanatic Muslims and was wary of Pan-Islamism which referred to the

91 Navis, Alam Terkembang, 28-29. Compare with Miryul MT Miron, ed., Direktori Minangkabau (Padang: BP-PAAM Batasangkar bekerjasama dengan LKAAM Sumbar, 2012), 345-346.

${ }_{92}$ Navis, Alam Terkembang, 21.

${ }_{93}$ Hamka, Islam dan Adat Minangkabau, 23-24.

${ }_{94}$ Miron, Direktori Minangkabau, 212-232. 
influence of the development of Islam in the Middle East. ${ }^{95}$ This policy was inseparable from the Dutch difficulties in breaking the Minang people's resistance. in the Paderi War which was driven by the ulema which was said to be influenced by the Wahabi movement. With regard to adat, contrary to the content of the Plakat Panjang agreement, the Netherlands actually provides a variety of "concessions" to traditional leaders. When the Dutch imposed forced cultuurstelsel as in other regions, the princes became colonial agents. The headman is also given the opportunity to punish people in his jurisdiction and forbid them from carrying out variants of work that are contrary to adat and all government regulations. ${ }^{96}$ The Netherlands then ransacked the traditional order of the Minang community by bringing up a shadow prince (rodi) in a special tribal leader to monitor the work of his own nephew when the politics of cultuurstelsel (forced cultivation) were carried out. The nagari leadership or government which is usually based on the agreement of the princes is pressured to choose one of them to lead the Nagari (the tuanku lareh now called wali nagari) ${ }^{97}$

Along with that, new policies in the form of association politics or ethical politics were rolled out. The aim is to build strong and intimate relations between colonists and colonizers that are carried out through the world of education. In the context of realizing education for indigenous children in accordance with the above ethical-political framework, the so-called liberal education politics was popularized. This politics is intended so that education can be developed in such a way that all groups and walks of life can be felt freely, easily, and openly. ${ }^{98}$ The first step to support these politics is to train a number of teachers who will be assigned to the intended educational institution. This was proven when in 1852 the school (Kweekschool) was established for the first time in Surakarta and in 1856 the popular school as the king's school (school for the ruler) had appeared in Bukittinggi. From the political framework above, it is certainly not surprising that most Kweekschool students are the children of the selected Tuanku Lareh, whose loyalty to the Dutch government is not in doubt. ${ }^{99}$ While the teaching staff are Dutch who

95 Aqib Suminto, Politik Islam Hindia Belanda (Jakarta: LP3ES, 1985), 203-204.

96 Daya, Gerakan Pembaruan, 164

${ }^{97}$ Rusli Amran, Sumatera Barat Plakat Panjang (Jakarta: Sinar Harapan, 1985), 193.

${ }^{98}$ Daya, Gerakan Pembaruan, 106.

${ }_{99}$ Djamal, DR.H. Abdul Karim Amarullah, 56. 
worked officially for the colonial government. Strangely, most of the Minangkabau Mudo community are graduates of this school including Sheikh Ahmad Khatib who was a teacher of the Kaum Mudo before leaving for the Grand Mosque. They were generally the children of officials or community leaders at that time so they had access to enjoy this exclusive Dutch education. While for indigenous children also established indigenous low schools or ILS (Indlansche Lagere School). HIS occupies the status of being the highest native school using Dutch as an introduction, studying for seven years and specifically intended for native students from respected families; position, descent, income, and education. Aside from methods, modern infrastructure, the fundamental difference between the traditional suran education system that has traditionally been carried out and the Dutch education above according to Karel A. Steenbrink lies in the education system that is managed in a modern manner and is centered on worldly knowledge and skills. While Islamic education lies in the skills and knowledge that are useful for religious appreciation, it is traditionally managed. ${ }^{100}$

Facing this situation, the Kaum Tuo as heirs and maintainers of the Islamic education system seem to be unaffected. Even showing the opposite symptoms, the Kaum Tuo are quite resistant to something that comes from the Netherlands or the Western World. They "forbid wearing neckties, suits, panties, and hats including forbidden fatwas from entering Dutch schools or at least violating Islam". ${ }^{101}$ Although they both studied with Sheikh Ahmad Khatib and accepted the suggestion to read books written by Islamic reformers (Jamāl al-Dīn al-Afghānī, Muḥammad 'Abduh and Muhammad Rashīd Rid̄ā), they chose a different path from their peers from the Kaum Mudo ranks. They still maintain the traditional education system surau despite the dynamics and socio-cultural demands they have said differently. Why haven't they changed? If this question is related to polemic issues between the two groups, it seems to be rooted in an ideological dispute on the subject of taqlid and ijtibäd. The Kaum Tuos insist on maintaining the attitude of taqlid, while the Kaum Mudo people prioritize ijtihād.

This ideological difference then becomes the root of their differences in responding to the presence of modernity values

100 Steenbrink, Pesantren, Madrasah, 24.

101 Noer, Gerakan Moderen, 9. 
together with the Dutch presence in the Minang realm. The Kaum Tuos showed a negative response by being resistant and suspicious of something new, especially from infidels such as the Dutch colonials who before when in the Paderi War had made the houses and mosques as hostels for the infidels. Even the mosque is often used as an arena for rape. ${ }^{102}$ While the Kaum Mudos as mentioned earlier no longer see modernity as a threat even though it is identical to the Netherlands or the West. Instead, they adopted certain progressive elements of the colonial education system that promised a cosmopolitan cultural atmosphere (progress). The problem is whether Western cultural elements can be domesticated so that progress is achieved, but community integrity (adat) and the rationality of faith and creed (Islam) are guaranteed as well? Community integrity is the main concern of adat stakeholders. With the authority and authority are given by the adat they maintain the continuity of the adat. Whereas rationality which demands total harmony between religious doctrines and social structures and behavioral systems is of concern to the scholars. Which is more important between the two? Is not the integrity of the community or community is a religious demand? But isn't the parallel between behavior patterns and religious teachings something imperative according to religious doctrine? This can be understood from Taufik Abdullah's thesis as a structural and cultural tension between adat, Islam and modernity. ${ }^{103}$ The dialectic has shifted the polemic between the Kaum Tuo and the Kaum Mudo in the early 20th century, from dialectical issues between adat and Islam to adat dialectics, Islam and modernity especially issue concerning Islamic education.

\section{Concluding Remarks}

In carrying out the Islamic reform movement, the Kaum Mudo were indeed involved in a polemic which was sometimes sharp and hard on the one hand with the Kaum Tuo (traditional-surau clerics) and on the other with the Indigenous people especially intellectuals educated by Dutch schools. It's just that this was done within the framework of negotiations as one of the character of the reformers. In certain parts of customs and traditions (tarekat) are criticized because they are considered not in line with the spirit of progress, but

102 Mansur, dkk., Sedjarah Minangkabau, 137; Amran, Sumatera Barat, 49.

103 Abdullah, Sebuah Diktum, 7. 
in other parts, it becomes the roots and estuaries of their Islamic reform movement. So far, the rhetoric and criticism of the Kaum Mudo, for example, against adat is actually not intended to damage or ignore it, instead, it strengthens it. In addition, as Muslim reformers, the Kaum Mudo are not completely free from the Minangkabau social structure that underlies and raises them. These social structures have provided social and intellectual advantages because they have placed them in the highest social hierarchy. They are strongly connected to the idea of progress that was the aspiration and obsession of the Minang people at that time.

The position as reformers is more reasonable because first of all, in addition to having to negotiate with social groups at the time, they must also negotiate with their own ethnic identity backgrounds, especially those born from mixed Minang and non-Minang families. Second, it appears in the reform model of the Thawalib and Diniyah Puteri Universities which selectively combines the progressive elements of the two models of the education system; the traditional Dutch modern and surau, also gives girls the same opportunity as boys to go to school. Third, it is also supported by the basic character of Minangkabau tradition which in its historical dynamics is not only related to and negotiating with Islam, but also with the issues of modernity that are present at the same time as the arrival of the invaders.

\section{Bibliography}

Abdalal, Rawi et.al, "Identity as a Variable", Perspectives on Politics, Vol. 4, No. 4, 2006.

Abdullah, Taufik. "Adat dan Islam: an Examination of Conflict in Minangkabau", Indonesia, No. 2, October 1966.

----. "Islam, History, and Social Change in Minangkabau", in Taufik Abdullah, ed., Change and Continuity in Minangkabau: Local, Regional, and Historical Perspectives on West Sumatra. Jakarta: LIPI, 1985.

----. "Sebuah Diktum Keramat dalam Sejarah Intelektual Minangkabau", Makalah pada seminar "Reaktualisasi Adat Basandi Syara' Syara' Basandi Kitabullah dalam Pembangunan Sumatera Barat", Bukittinggi, 22-23 Januari 2000.

----- Schools and Politics: The Kaum Muda Movement in West Sumatra 1928-1933. Jakarta-Kuala Lumpur: Euinox Publishing, 2009. 
Amran, Rusli. Sumatera Barat Plakat Panjang. Jakarta: Sinar Harapan, 1985.

Arsa, Dedi. "Perempuan Memberontak: Perlawanan Perempuan Minangkabau terhadap Kolonialisme Belanda di Sumatera Barat 1908-1942”, Kafa'ah Journal, Vol 7, No. 1, 2017.

Ashadi, Andri dkk. Tradisional di Tengah Perubahan Studi Kasus Pesantren Salafiah Kabupaten Padang Pariaman. Padang: Puslit IAIN Imam Bonjol Padang, 2011.

Asnan, Gusti. Kamus Sejarah Minangkabau. Padang: PPIM, 2003.

Assyaukanie, Luthfi. "Islamic Reform Movement in Indonesia and Beyond: Progress and Regress", Journal of Indonesian Islam, Vol. 2, No. 01, 2008.

Azra, Azyumardi. "The Transmission of al-Manar's Reformism the Malay-Indonesian World: The Cases of al-Imam and al-Munir," Studia Islamika, Vol. 6, No. 3, 1999.

-----. Surau Pendidikan Islam Tradisional dalam Transisi dan Modernisasi. Jakarta: PPIM UIN Syarif Hidayatullah Jakarta, 2017.

Daya, Burhanuddin. Gerakan Pembaruan Pemikiran Islam Kasus Sumatera Thawalib. Yogyakarta, Tiara Wacana, 1990.

Djamal, Murni. DR.H. Abdul Karim Amarullah Pengarubnya dalam Gerakan Pembaharuan Islam di Minangkabau pada Awal Abad ke-20. Jakarta: INIS-Leiden, 2002.

Elfira, Mina. "Bundo Kanduang: a Powerful or Powerless Ruler? Literary Analiysis of Kaba Cindua Mato (Hikayat nan Muda Tuangku Pagaruyung)", Makara Sosial Humaniaro, Vol. 11, No. 1, 2007.

Hamka. Ayahku. Djakarta: Jayamurni, 1967.

----. Islam dan Adat Minangkabau. Jakarta: PT Pustaka Panjimas, 1984.

Hadler, Jeffrey. Sengketa Tiada Putus Matriarkat, Reformasi Islam, dan

Kolonialisme di Minangkabau, trans. Samsudin Berlian. Jakarta: Freedom Institute, 2010.

Irhash A. Samad and Chaniago, Danil M. Islam dan Praksis Kultural Masyarakat Minangkabau. Jakarta: Tintamas, 2007.

Lickson, Charles P. J.D., and Maddux, Robert B. Negotiation Basics Win-Win Strategies for Everyone, Fourth Edition. Canada: Transcontinental Printing, 2005.

Minami, Daisuke. "Normalizing" Japan?: Contestation, Identity, Construction, and the Evolution of Security Policy", Honor Project, Paper 39, 2013. 
Kamaluddin, Safruddin Halimy. Adat Minangkabau dalam Perspektif Hukum Islam. Padang: Hayfa Press, 2005.

Lauer, Robert H. Perspektif tentang Perubahan Sosial. Jakarta: Bina Aksara, 1989.

Mansoer, M.D. dkk., Sedjarah Minangkabau. Djakarta: Bhratara, 1970.

Miron, Miryul MT ed. Direktori Minangkabau. Padang: BP-PAAM Batasangkar bekerjasama dengan LKAAM Sumbar, 2012.

Nasution, Harun. Pembaharuan dalam Islam Sejarah Pemikiran dan Gerakan. Jakarta: Bulan Bintang, 2002.

Nasrullah. "Respons dan Tantangan Kaum Tua atas Kritik Kaum Muda terhadap Tarekat di Minangkabau", 'Anil Islam, Vol. 9, No. 2, 2016.

Nasroen. Dasar Falsafah Adat Minangkabau. Jakarta: Bulan Bintang, 1989.

Noer, Deliar. Gerakan Moderen Islam di Indonesia 1900-1942. Jakarta: LP3ES, 1988.

Rais, Zaim. Against Islamic Modernism: The Minangkabau Traditionalists Responses to the Modernist Movement. Jakarta: Logos, 2001.

Ronsi, Gusna. "Citra Perempuan dalam Peribahasa Etnik", Wacana Etnik: Jurnal Ilmu Sosial dan Humaniora, Vol. 2, No. 1, 2011.

Ropi, Ismatu. Religion and Regulation in Indonesia. Singapore: Palgrave Macmillan, 2017.

Rusmali, Marah dkk. Kamus Minangkabau-Indonesia. Jakarta: Pusat Pembinaan dan Pengembangan Bahasa Departemen Pendidikan dan Kebudayaan Jakarta, 1985.

Saputra, Rony. Ketika Kebebasan Beragama, Berkeyakinan, dan Berekspresi Diadili. Padang: LBH Padang, 2013.

Saerozi, Muh. "Model of Strategies in Developing Islamic Thought through Curriculum: a Study of Sumatra Thawalib 1900-1942", IJIMS: Indonesian Journal of Islam and Muslim Societies, Vol. 4, No. 2, 2014.

Siswayanti, Novita. "Muhammad Djamil Djambek: Ulama Pembaharu Minangkabau”, Jurnal Lektur Keagamaan, Vol. 12, No. 2, 2014.

Stark, Alexander. "The Matrilineal System of the Minangkabau and its Persistence Throughout History: A Structural Perspective", Southeast Asia: A Multidisciplinary Journal, Vol. 13, 2013.

Steenbrink, Karel A. Pesantren, Madrasah, Sekolah Pendidikan Islam dalam Kurun Moderen. Jakarta: LP3ES, 1986. 
Suminto, Aqib. Politik Islam Hindia Belanda. Jakarta: LP3ES, 1985.

Suryo, Djoko dkk. Agama dan Perubaban Sosial Studi tentang Hubungan antara Islam, Masyarakat dan Struktur Sosial Politik Indonesia. Yogyakarta: LKPSM, 2001.

Syarifuddin, Amir. “Adat Basandi Syara' Syara' Basandi Kitabullah”, dalam kumpulan makalah "Seminar Reaktualisasi Adat Basandi Syarak, Syarak Basandi Kitabullah dalam Pembangunan Sumatera Barat", Bukittinggi, 22-23 Januari 2000.

Tammey, Joseph. "Modernization and Religious Purification: Islam in Indonesia", Review of Religious Research, Vol. 22, No. 2, 1980.

Ting-Toomey, Stella. Communicating Across Cultures. New York London: The Guilford Press, 1999.

Udrea, Georgiana and Dumitriu, Diana Luiza. "Identity and Intercultural Adaptation Students' Adjustment Process to European Environments," International Conference RCIC'15 Redefining Community in Intercultural Context, Brasov, 21-23 May 2015.

Wahib, Ahmad Bunyan. "Being Pious Among Indonesian Salafis", Al-Jami'ah: Journal of Islamic Studies, Vol. 55, No. 1, 2017.

Wanto, Adri. "The Paradox Between Political Islam and Islamic Political Parties: The Case of West Sumatera Province", AlJami'ab: Journal of Islamic Studies, Vol. 50, No. 2, 2012.

Yunus, Mahmud. Sejarah Pendidikan Islam di Indonesia. Jakarta: T. Hidakarya Agung, 1996.

Zed, Mestika ed. Pemikiran Minangkabau Catatan Budaya A.A. Navis. Bandung: Angkasa, 2017.

Zulmuqim. "Transformation of the Minangkabau Islamic Education: The Study of Educational thought of Abdul Karim Amrullah, Abdullah Ahmad and Rahmah El-Yunusiyah," al-Ta'lim Journal, Vol. 22, No. 2, 2015. 